\title{
Introduction: Drastic Rural Changes in the Age of Land Reform
}

\author{
Shinichi Takeuchi
}

\begin{abstract}
This introductory chapter presents the objectives and interests of the book as well as important topics that will be addressed in the following chapters. The main purpose of the book is to reflect upon the meanings of drastic African rural changes by analysing recent land reform. Whereas the stated objectives of land reform were relatively similar, that is, strengthening the land rights of users, the experiences of rural change in Africa in the same period have been quite diverse. In this context, this book conducts a comparative analysis, with in-depth case studies to seek reasons that have brought about different outcomes. From the second to fourth sections, we provide an overview of the characteristics of customary land tenure, the pressure over, and change in, African land, and backgrounds of recent land tenure reform. The fifth section considers what land reform has brought to African rural societies. It is evident that land reform has accelerated the commodification of African customary lands. In addition, the political implications of land reform will be examined. The case studies in this book will clarify some types of relationships between the state and traditional leaders, such as collusion, tension, and subjugation. It is likely that these relationships are closely related to macro-level political order and state-society relations, but further in-depth research is required to understand these issues.
\end{abstract}

Keywords Land reform $\cdot$ Rural change $\cdot$ State $\cdot$ Traditional leader $\cdot$ Customary land $\cdot$ Africa

\section{Investigating Rural Change Through the Lens of Land Reform}

Since the 1990s, sub-Saharan African countries ${ }^{1}$ have been actively involved in land reform. While this includes various types, the most conspicuous has been reform in

\footnotetext{
${ }^{1}$ In this book, the term 'Africa' can be used interchangeably with sub-Saharan Africa, if there is no additional explanation.
}

S. Takeuchi $(\varangle)$

African Studies Center, Tokyo University of Foreign Studies, Fuchu, Japan

e-mail: shinichi_takeuchi@tufs.ac.jp

S. Takeuchi (ed.), African Land Reform Under Economic Liberalisation, https://doi.org/10.1007/978-981-16-4725-3_1 
the institutions regarding land, namely land tenure reform. More than 40 sub-Saharan African countries revised or created new land-related laws or prepared land-related bills during this period. In addition, some countries, including Namibia, South Africa, and Zimbabwe, conducted redistributive land reforms (Martín et al. 2019). Generally, these reforms have been achieved with the assistance of Western donors.

In the same period, African rural society has seen dramatic changes that have had various aspects and far-reaching implications. The rapid and significant commercialisation of land has been one of the most conspicuous features of these changes, and the steep increase in large-scale land deals in Africa has attracted worldwide attention (Sassen 2013). In the past couple of decades, a gargantuan swathe of land has been put under deals for the purpose of exploiting commodities including food, biofuels, timber, and minerals. Another important change in the period is the integration of African rural society into the state. Despite popular images of the 'uncaptured peasants' (Hyden 1980), as well as the 'limited power over distance' (Herbst 2000), some African states have recently strengthened their control over rural society through various policies, particularly on decentralisation, agriculture, forestry, and land.

The age of land reform overlapped with the age of drastic rural changes. The relationship between these two factors warrants investigation. However, we should not fall into reductionism. Land reform does not explain everything. In many cases, the reform itself cannot be considered a major cause of change, but we believe that thinking about current African rural change through the lens of land reform will be relevant.

The first reason is the potential significance of the impacts of land reform. Land constitutes one of the most important pillars of African rural societies, and therefore, policy interventions over the land are likely to have some impact, while their extent will naturally vary. Land tenure reform since the 1990s has mainly endeavoured to transform the nature of customary land, which accounts for a vast majority of African rural area, and in fact, it is there that the most significant changes have been taking place. A detailed analysis of the impacts of the reform will, therefore, clarify the realities on the ground and shed light on the mechanism of recent rural changes.

The second reason is that focussing on land reform, particularly land tenure reform, will make comparisons among case studies effective and meaningful, because African land reforms since the 1990s have been conspicuous not only in terms of the number of countries that have undertaken them, but also in the similarity of their objectives (Martín et al. 2019). In fact, land tenure reforms in this period have attempted to clarify and strengthen the land rights of users. Despite the implementation of similar policies, the features of rural changes have varied considerably. For example, the size of land deals, the intensity of policy implementation, and the role of traditional leaders are extremely diverse from one country to another. Investigating the reasons for this variation will contribute significantly to the understanding of recent rural changes.

The aim of looking through the land reform lens is to examine why similar policies have produced different outcomes. The contributors to this book conduct in-depth analyses focussing on three main stakeholders, namely the state, traditional leaders, 
and the community. When representing those who design and implement the reform, the state may refer to a government, its officials, or a ruling party. Traditional leaders have been closely interested parties in the reform. In many African countries, their status and prerogatives over land were officially recognised through the reform. The community is composed of people, such as farmers and herders, who are directly concerned with the reform. With a focus on the stakeholders, each chapter considers the motivations, context, and outcomes of land reform.

This introductory chapter begins with an examination of the nature of customary land, which has accounted for the largest part of African rural areas and has been an arena of drastic changes for a couple of decades. The third section reveals that customary land has recently been put under significant pressure due to rapid population increase and the strong demand for land leasing. The fourth section provides a background to land reform since the 1990s and offers reasons why many African countries simultaneously launched reforms in this period. The paper then explores the outcomes of land law reform, which have had strong socio-economic and political implications to date.

\section{Customary Land Tenure in Africa}

African countries are generally characterised by the importance of customary land, which accounts for an immense portion of its rural areas. Although there are no reliable data, the average percentage of land registered under private titles is considered to be less than $10 \%$ in Africa (Boone 2014, 23). With the exception of a limited number of countries, such as South Africa, in which the proportion of registered land has been exceptionally high, ${ }^{2}$ customary land has generally prevailed in rural areas of African countries.

Who has what kind of rights in customary land varies, according to the historical process through which the user, namely the community, has been organised and has evolved. Families and their kin often have effective control over the land, but chiefs may claim allodial rights, and other social groups, including migrants and pastoralists, may also have the right to claim. Even in cases where the state is its official owner, the management of customary land is effectively handled by non-state actors, thus making the rights socially embedded. Consequently, multiple actors can claim their rights over customary land, and the rights of direct users are likely to be limited compared with the state-controlled land tenure system, such as freehold and leasehold. It can be occupied, cultivated, and inherited within families provided they are self-managed, but selling and purchasing the land is tightly restricted.

Customary land tenure should be distinguished from 'communal land tenure' or 'common ownership'. Customary land includes two different areas regarding the rights of an individual. In areas in which fixed persons continuously use and work,

\footnotetext{
${ }^{2}$ The proportion was $72 \%$ in South Africa, $44 \%$ in Namibia, and $41 \%$ (or $33 \%$ ) in Zimbabwe (Boone 2014, 23).
} 
the community recognises and respects their particular rights. For example, farmland is managed by individuals and families who have strong rights to it (Bruce 1988, 24). Conversely, there are commonages, such as forests and prairies. In these areas, community members have equal rights for gathering, hunting, and grazing. Often, outsiders in the community have benefitted from the commons. The coexistence between farmers and herders is a typical example. Although such a mutually beneficial relationship has been increasingly difficult to maintain, coexistence remains observable thus far (Bukari et al. 2018).

Customary land tenure should not be identified using a 'traditional' system. Although it may include elements of the precolonial land tenure system, it has been repeatedly reorganised and transformed since colonial times (Chanock 1991; Amanor 2010). When separating the territory for Africans and Europeans, the colonial authority stipulated that the former should be ruled by customary laws. In other words, the customary land was placed outside statute law in the colonies. Private property rights were denied there, and rights for the redistribution and disposition of lands were attributed only to specific actors, such as traditional leaders, whose powers were systematically reinforced by the colonial authorities. This bifurcated land tenure system persisted in post-colonial African states, in which rural areas were put under customary land tenure, although its nominal ownership was usually attributed to the state or the president.

The flexibility of customary land tenure has been considered a conspicuous feature. Despite a transformation in the colonial period, in which the roles and functions of traditional authorities were empowered and institutionalised, customary land tenure has had some leeway or negotiable areas so that community members could deal with difficulties in their lives (Berry 1993; Moore 1998). Importantly, customary tenure reflects hierarchical relationships existing both within social groups and between them (Bruce 1988), thereby constituting a multi-layered structure of various rights. The fact that many individuals have a say in its uses and transactions makes various rights related to customary land flexible, negotiable, and ambiguous. This is not to say that customary land tenure is always inclusive. Researchers have been increasingly aware that it may also work for the marginalisation and exclusion of vulnerable groups in the community (Amanor 2001; Peters 2002).

\section{Pressure on, and Changes in, the African Land}

The chapters of this book will demonstrate in detail that recent years have seen dramatic rural changes, with increasing pressure on customary land in Africa. One of the most basic and visible factors is population increase. The population density exceeded 100 persons per $\mathrm{km}^{2}$ in only four small countries in 1961, but that number of countries grew to 15 in 2018 (Table 1). Africa's population density has been increasing so rapidly that it can no longer be characterised as a land-abundant and labour-scarce continent. Despite the marked tendency of urbanisation, $60 \%$ of 
Table 1 Evolution of population density in Africa

\begin{tabular}{l|l|l}
\hline Population density & 1961 & 2018 \\
\hline More than 300 persons $/ \mathrm{km}^{2}$ & Mauritius (335) & $\begin{array}{l}\text { Burundi (435), Comoros (447), } \\
\text { Mauritius (623), Rwanda (499) }\end{array}$ \\
\hline 200-299 persons $/ \mathrm{km}^{2}$ & $\begin{array}{l}\text { Gambia, Nigeria, Sao Tome and } \\
\text { Principe, Seychelles, Uganda }\end{array}$ \\
\hline $100-199$ persons $/ \mathrm{km}^{2}$ & Burundi, Comoros, Rwanda & $\begin{array}{l}\text { Benin, Cabo Verde, Ghana, } \\
\text { Malawi, Sierra Leone, Togo }\end{array}$ \\
\hline
\end{tabular}

Source World Bank, World development indicators

the population in sub-Saharan Africa currently lives in rural areas, ${ }^{3}$ indicating that African rural areas have generally seen intense land pressure. ${ }^{4}$ Despite the general tendency of rapid population increase, it should be noted that African population densities are not evenly spread due to historical, environmental, and agro-ecological factors. The sparsely populated areas have been targeted for the recent expansion of investments, as mentioned by the World Bank (2009).

The growing demand for farmland is another important pressure on customary land. The economic liberalisation policies implemented since the 1980s and the subsequent hyperglobalisation and economic boom in African natural resources, minerals, and agricultural commodities have greatly accelerated this trend. African countries have attracted enormous direct investments in the agricultural, mining, and forestry sectors since the 2000s. This culminated in the 2008 world food crisis as foreign and national capitals competed in acquiring African lands. The magnitude of land deals in recent Africa has been enormous. As Land Matrix data ${ }^{5}$ indicate (Tables 2 and 3), land deals for agriculture, as well as timber production, have been immense in some countries, occupying considerable portions in comparison with arable land and forest land, respectively. When considering that the Land Matrix has only begun to collect data since the year 2000, this indicates that land in rural Africa has been subjected to land deals with surprising speed for these two decades.

The Land Matrix data also show the diversity of land deals. While land deals have generally increased in Africa, their size and nature vary significantly from one country to another. The impact of the land deals will be potentially immense in Sierra Leone and Madagascar when considering their proportion of arable land ${ }^{6}$ (Table 2). The high number of land deals in Ethiopia, Senegal, and Mozambique for agricultural land (Table 2), as well as DR Congo for forest land (Table 3), indicates that these governments have been eager to attract investments. Significant land deals have been made

\footnotetext{
${ }^{3}$ In 2018, the rural population in sub-Saharan Africa accounted for $59.8 \%$ of the total population (data from the World Development Indicators). Although its decreasing tendency has been clear because it was $81.9 \%$ in 1970 , the proportion of the rural population remains significant in Africa compared with other regions in the world.

${ }^{4}$ Average rate of rural population increases per year in sub-Saharan Africa between 1960 and 2019 was $2.08 \%$ (World Development Indicators).

${ }^{5}$ Retrieved from Land Matrix Data (https://landmatrix.org/data/) on 14 March 2021.

${ }^{6}$ Their real impacts are yet to be seen, because only a part of the contracted land has been operational.
} 


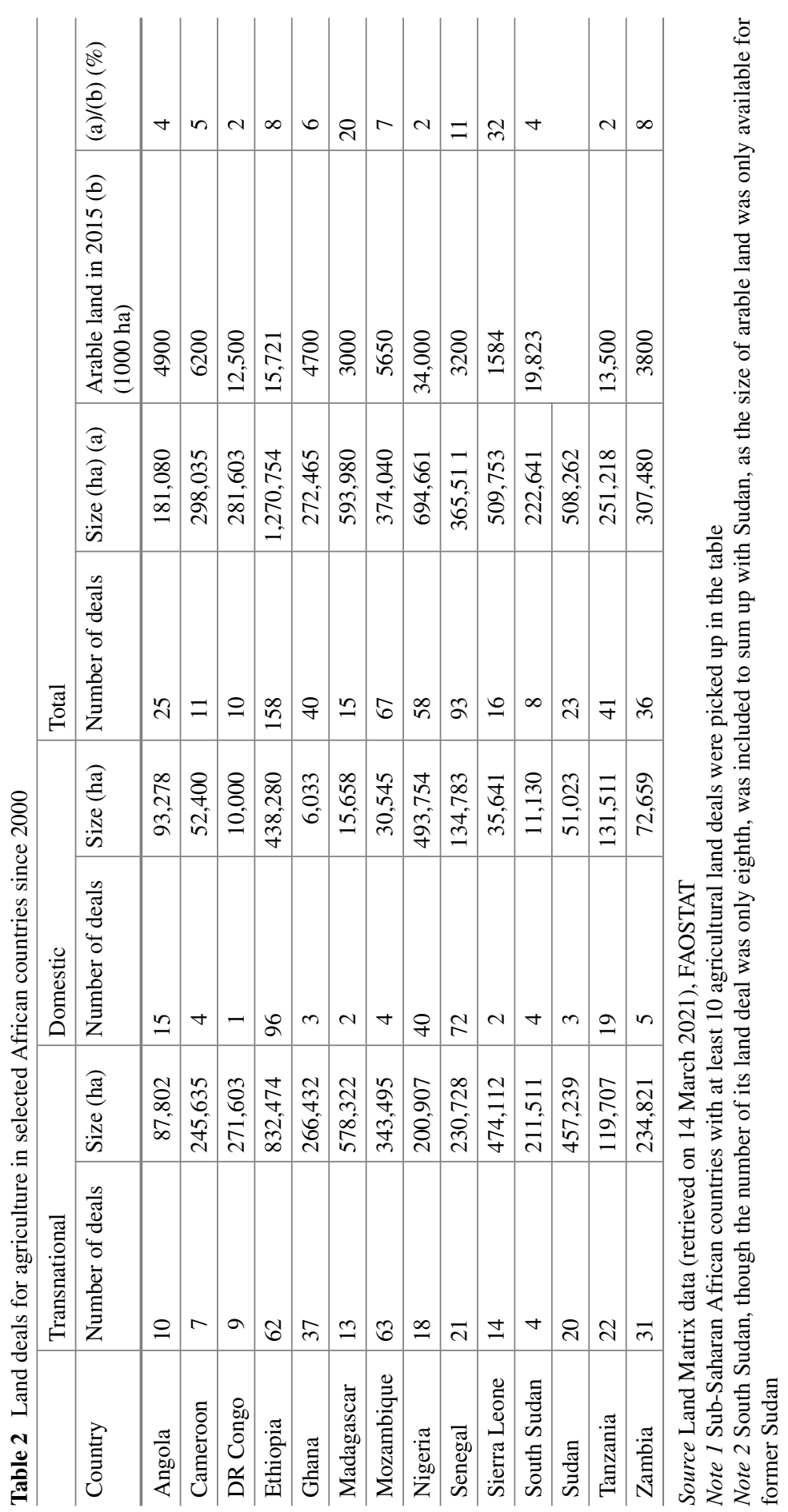




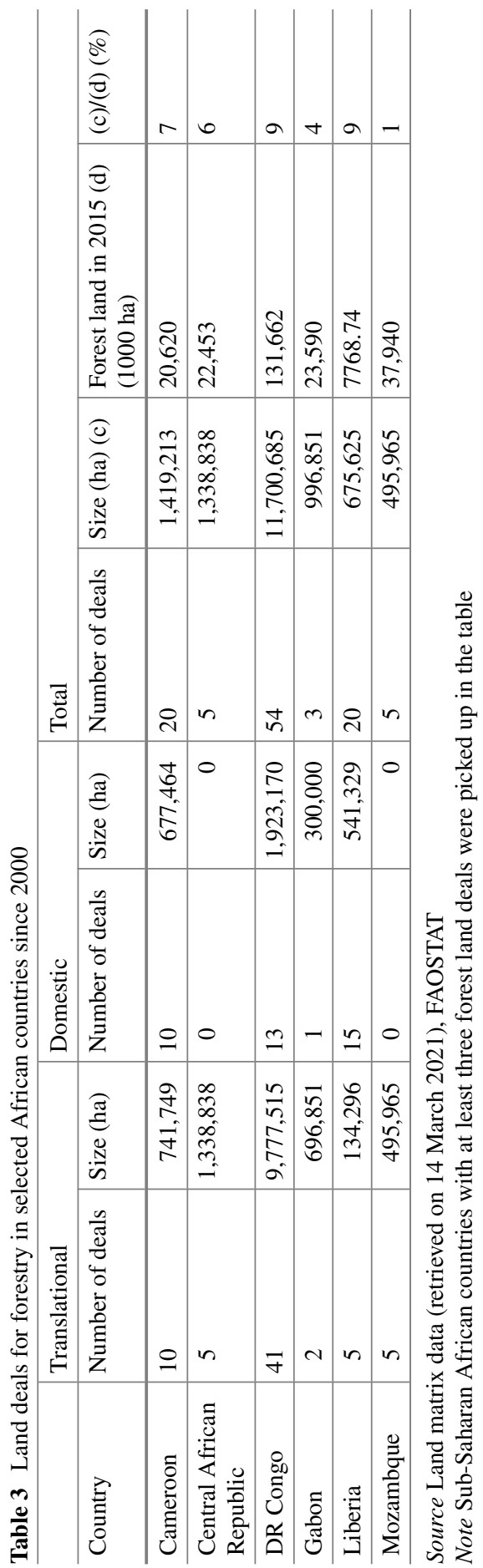


by domestic actors in countries such as Ethiopia, Nigeria, and Senegal, illustrating that the government and domestic private companies have actively engaged in agricultural investment. The Land Matrix data only include land deals larger than 200 ha, and considering that the average land deal size of domestic actors tends to be smaller than that of transnational actors, it is likely that domestic actors have conducted innumerable smaller land deals, as shown in Chapter 4 'Renewed Patronage and Strengthened Authority of Chiefs Under the Scarcity of Customary Land in Zambia'.

It is clear that an important portion of African land has been leased to foreign and national capitals in a short period of time, thereby depriving rural communities of their customary land. The expansion of foreign investment in farmland has been sanctioned by governments and justified in terms of the marginality or underutilisation of the land. This has usually targeted lands that were used by rural communities, where ownership rights were weak, including commonages, grazing lands, forests, and lands used by migrants and the most marginalised members of communities (Deininger and Byerlee 2011; Peters 2013). In other words, they were areas that had been considered 'unowned, vacant, idle, and available' (Alden-Wily 2011, 736).

With the adoption of neo-liberal policies, African governments have competed with each other to attract foreign direct investment (FDI). Although many governments have introduced new land policies and laws that purport to increase the recognition of customary land ownership, this has recognised land as a marketable commodity, paving the way for investors to gain market access to customary land at the expense of rural users and leading to increased speculation in land at the international and national levels. The reduced availability of customary land has seriously affected the lives of rural African people. It is evident that the marked increase in land conflicts in recent times is linked to increasing pressures on customary lands resulting from population increase and investments (Takeuchi 2021).

\section{Backgrounds to Land Reform}

Two types of land reforms have recently been conducted in Africa. The first type is redistributive land reform conducted in countries such as South Africa, Namibia, and Zimbabwe. The principal objective of this reform is to redress the significant inequality in land holdings due to historical legacies. The central debate in this type of land reform has been, therefore, the transfer and redistribution of land owned by white farmers. The second type of land reform is the revision or creation of landrelated laws and institutions without the redistribution of land. ${ }^{7}$ The main target of

\footnotetext{
7 The two types are not mutually exclusive. While Ethiopia has actively carried out reform over land management since the 2000s, it pushed through land redistribution following the revolution in 1974. Rwanda also made a radical redistribution of land in favour of Tutsi returnees before the implementation of the land tenure reform in the 2000s (Chapter 7 'Land Law Reform and Complex State-Building Process in Rwanda'). Along with land reform for redistribution, Namibia, South Africa, and Zimbabwe undertook land tenure reform in their communal lands (Chapter 5 'Land Tenure Reform in Three Former Settler Colonies in Southern Africa').
} 
this reform has been similar, and by focussing on customary land, it has endeavoured to transform its management to clarify and strengthen the rights of users and facilitate the delivery of land titles. This type of land reform has prevailed since the 1990s. Its proliferation is surprising because more than 40 African countries have revised or newly created land-related laws or have attempted to do so (Martín et al. 2019).

Why have African countries simultaneously begun to revise the management of customary land? Manji (2006) emphasised the influence of neo-liberal thoughts behind land tenure reform in this period. Following the end of the Cold War, neoliberal ideology became dominant among donors, according considerable influence over their aid policy in general, and the policy for land and property in particular. It has been argued that, together with the strong popularity of de Soto (2000), the idea that providing the land with private property rights should promote economic development was widely accepted among policymakers.

Although the neo-liberal ideology has been undeniably influential, the story seems to have not been so straightforward. First, many scholars were sceptical of de Soto's optimistic view as well as land tenure reforms, which gave them a feeling of déjà vu. Arguments stressing the necessity of private land rights for the growth of agricultural production had already arisen in the colonial period, and a number of settlement programmes were implemented for this purpose in colonies, including British East Africa (Kenya) and the Belgian Congo. ${ }^{8}$ Regarding the settlement programme inherited by independent Kenya, the World Bank, which has consistently advocated for the introduction of private land rights, gave it high praise in its report (World Bank 1975, 71). However, scholars were bitterly critical of its outcomes (Coldham 1978, 1979; Shipton 1988; Haugerud 1989). Consequently, the negative outcomes of programmes transforming customary tenure into 'modernised' tenure strengthened 'a conviction that the glosses of customary and communal tenure have caused more trouble than not' (Peters 2002, 51). There was a broad consensus among scholars in the 1980s that customary land tenure worked efficiently and effectively with market-oriented agriculture and met the needs of small-scale farmers in Africa. Even the World Bank scholars recognised the merits of flexible land use in customary tenure and stated that 'as long as there is effective governance, communal tenure systems can constitute a low-cost way of providing tenure security' (Deininger and Binswanger 2001, 419).

To explain the proliferation of land tenure reforms in Africa since the 1990s, two factors should be considered. The first factor clearly recognised that customary land tenure faced daunting problems (Bruce 1988). Whereas state-led land reform has had serious drawbacks (Sikor and Müller 2009), challenges in, and threats to, customary land tenure, including expanding inequalities, social exclusions, and excessive concentration of land, have been increasingly clear (Peters 2013). Importantly, policy debates on African agriculture in the 1990s tended to centre on its low

\footnotetext{
${ }^{8}$ In Kenya, the British colonial government launched the so-called Swynnerton Plan in 1954, promoting private properties for African farmers. The policy providing private land rights for farmers was inherited by the independent Kenyan government. The Belgian Congo has implemented a similar policy called 'paysannat' since the 1930s (Staner 1955; Bonneuil 2000). By providing a parcel of land, the policy aim was to foster small farmers with modern techniques, but this was abandoned after independence.
} 
productivity following the serious economic crisis of the 1980s (Peters 2002, 51). In this context, it was widely argued that customary land provided only ambiguous rights for users, thereby reducing incentives for farmers to invest in their lands and, therefore, resulting in low agricultural productivity (Feder and Noronha 1987). Although this logic promoting private property was not new, it was enthusiastically accepted in this period by donors as well as African policymakers.

The second factor was that changes in development strategy had a significant influence. Following the introduction of the Structural Adjustment Policy (World Bank 1981), small farmers were the focus in the strategy for development in Africa. The basic premise of this argument was 'the desirability of owner-operated family farms' (Deininger and Binswanger 2001, 407). However, the focus began to change in the 2000s as the African economy expanded. In the context of 'Africa rising', the governments became significantly more interested in attracting FDIs to boost economic growth and promote rural development. As a result, African countries have generally adopted both policies for formalising/legalising customary land rights (Ubink, 2009) and for promoting FDI at the same time. For example, Ethiopia, which had taken a pro-poor agricultural policy in the 1990s, radically shifted its policy agenda in the 2000s in order to promote market economies and attract FDI (Lefort 2012).

This policy change was also introduced and embraced by donors, who have consistently hoped to increase their investments and encourage African countries to establish adequate laws and institutions for this purpose. The popularity of de Soto (2000) should be understood in this context. Such design and intention were reinforced by the global food crisis in 2007-08 (World Bank 2009) and culminated in the New Alliance for Food Security and Nutrition launched in 2012. ${ }^{9}$ Land tenure reform had aimed at strengthening the rights of users, but it was investors, and not small farmers, who saw the land rights secured.

Mainstream economists have recommended the formalisation of customary land rights with a low-cost method as a desirable policy option. ${ }^{10}$ In particular, the World Bank has been eager to advocate for technical innovation in low-cost land registration (Deininger et al. 2010; Shen and Sun 2012). However, land registration will neither automatically activate investment nor guarantee agricultural development. Its effects vary considerably and depend heavily on politics and governance, which is the very reason why experts in Africa have taken a cautious stance on this issue (Peters 2002; Sjaastad and Cousins 2009). Although some World Bank researchers have been clearly aware of the close relationship between the effects of land registration and governance (Deininger and Feder 2009), it is highly questionable to what extent this understanding has been shared with policymakers in general.

\footnotetext{
${ }^{9}$ The New Alliance is a policy framework adopted at the G8 summit under the US presidency and has been repeatedly criticised of its prioritising private companies over small farmers.

${ }^{10}$ Compared with the 'land to tiller' policies (tenancy reform) and the market-assisted land redistribution reforms, Holden et al. recommended the low-cost land registration and certification programme because it successfully enhanced investment, land productivity, and land rental activity (Holden et al. 2013, 16).
} 
Although land tenure reform has been donor-driven, it does not mean that donors have unilaterally imposed it upon African governments. Some of them have been clearly conscious of its importance and have taken the opportunity to utilise external resources to strengthen the states' abilities to control lands and rural communities. The formal objective of the recent land tenure reform is to establish a unitary system for land management. Given that land is an important resource for political mobilisation, the state has naturally strong motivations to pursue reform to strengthen its control. Our case studies show that countries such as Mozambique and Rwanda had clear objectives for power consolidation in introducing land tenure reform (Chapters 'Politics of Land Resource Management in Mozambique' and 'Land Law Reform and Complex State-Building Process in Rwanda').

\section{What the Land Tenure Reforms Have Produced}

\subsection{Commodification of Customary Land}

What have land reforms undertaken since the 1990s given rise to in Africa? How are they related to the drastic rural changes during the same period? One of the most broadly recognised outcomes is the accelerated commodification of customary land and its vast transfer from rural communities. Following the detailed examination of African land reforms, Martín et al. (2019) concluded that the recent land reform facilitated land privatisation in exchange for customary lands. According to Alden-Wily (2014), land reform started in the 1990s with the aim of simultaneously protecting the rights of users in customary land and improving investors' accessibility. Although the reform had a vision of community-driven and pro-poor development, it was replaced by a development strategy through large-scale commercial agriculture during the land rush in the 2000s.

In the second section, we saw how the expansion of land deals in Africa was rapid and immense. Undoubtedly, this is one of the most conspicuous aspects of the recent rural changes. It is obvious that land tenure reform has promoted transactions in the market by facilitating the issue of land titles. Among our case studies, Chapter 6 'Politics of Land Resource Management in Mozambique', which deals with the Mozambican case, indicates this the most clearly. Despite the renowned reputation of land law respecting customary rights, the country has seen a vast swathe of land transfer for foreign private companies. The chapter illustrates how the government has intentionally utilised laws and institutions to invite FDIs.

As discussed above, foreign companies have not been the only sources of the rising demand for land. National actors also matter. The recent land law reform has not only facilitated governmental actions for the delivery of land titles but has also had significant influence on local actors by inspiring various initiatives. This point is clearly described in Chapter 4 'Renewed Patronage and Strengthened Authority of Chiefs Under the Scarcity of Customary Land in Zambia', which indicates a 
case observed in north-eastern Zambia. Against the backdrop of the empowerment stipulated by the 1995 Land Act, chiefs issued their own land titles and sold them to outsiders. For city dwellers, including retired employees, the customary land in rural areas is a valuable asset that functions as social security. This has sharpened the sense of crisis among local residents who have increasingly experienced land scarcity. This chapter echoes previous literature that stresses the recent development of enclosures in Africa (Woodhouse 2003).

\subsection{Political Implications of Land Reform}

When dealing with the fundamental means of production, land reform has strong implications for politics. The political significance, effects, and implications of land law reform in Africa have been addressed in a number of studies (Boone 2014, 2018a, b; Takeuchi 2014; Lavigne-Delville and Moalic 2019). Martín et al. (2019, 603) regarded the recent land law reforms in Africa as 'a return to former colonial policies', because they have revived the role of traditional authorities. The idea of rolling back the state has been widely shared among Development Assistance Committee (DAC) donors and recipient countries since the 1990s, and therefore, traditional leaders have been empowered by the process of land tenure reform. However, rural changes during this period have been varied and complex.

Variations in rural changes have been partially attributed to the motivations and interests of stakeholders. Consider the example of donors who have been key stakeholders in land law reform. The donors pursued two different and sometimes contradictory, objectives during this period. Firstly, they requested that the African states release land ownership and that land management be decentralised. The state should retreat from socio-economic activities and be replaced by the market. Therefore, donors assisted and funded land tenure reform, often in parallel with the decentralisation policy line of thought. Conversely, donors have also wanted African states to be competent and efficient in preventing internal conflict, controlling 'terrorist' activities, and facilitating economic management. State building has been considered key to this objective, and significant assistance has been provided to strengthen the capability of the state (OECD 2008a). Such considerations have been increasingly necessary for donors because they have regarded state fragility as one of the core problems of Africa (OECD, 2008b). The attitudes of donors towards democratisation and decentralisation have been ambiguous since the 2000 s because of these contrasting interests.

Similar to donors, African stakeholders have had diverse motivations for, and interests in, land tenure reform. Naturally, traditional authorities have keen interests in strengthening their power over land. Although the arguments of donors for decentralising land management have been expedient for them, whether or to what extent traditional leaders benefit from the reform has been heavily dependent on their relationships with the state. In Ghana, for example, traditional chiefs have strong and institutionalised power and have built close links with official political systems, 
including the bureaucracy and political parties. Because of the strong political power of the chiefs, state officials are generally reluctant to engage in land-related issues and act against the benefit of chiefs (Ubink 2007). In such circumstances, when characterised by collusion between chiefs and state officials, land tenure reform would not bring about meaningful changes in the land management system (Amanor 2009). Chapter 2 'Land Administration, Chiefs, and Governance in Ghana' elucidates how the relationship between the Ghanaian state and chiefs has been forged because of long-term interactions since the colonial period.

The relationship between the state and traditional leaders can be strained. In Zambia, traditional chiefs demonstrated their strong opposition to the proposed new land policy in 2018, claiming that it would undermine their roles on the land (Chapter 3 'We Owned the Land Before the State was Established': The State, Traditional Authorities, and Land Policy in Africa'). Although the roles of Zambian traditional authorities are clearly mentioned in the 1995 Land Act, ${ }^{11}$ and they have actually maintained their significant role in land management in rural areas, the chiefs have been quite suspicious of land law reform. This is understandable because land law reform is inherently an attempt to formulate law and order officially prioritising the state over other political forces. The demonstration staged by the chiefs clearly illustrates the tension between traditional authorities and the state.

The relationship between the state and traditional leaders reflects their power relationships that have been forged in a long history. In the case of Ghana and Zambia, where traditional leaders hold relatively strong power, the relationship has been characterised by collusion and tension. In other countries, however, the state has had overwhelming power and subjugated traditional leaders, or even monopolised the political space, thereby utilising land policies as a tool for power consolidation.

Mozambique is a representative case, whereby the state has subjugated and manipulated traditional leaders. In the country, the rural community has been fundamentally reorganised in parallel with land tenure reform. The reorganisation was pursued by the ruling party (Frente de Libertação de Moçambique: Frelimo) to strengthen its control over rural areas. Chapter 6 'Politics of Land Resource Management in Mozambique' demonstrates that the ruling party, considering control over rural areas as critical for political dominance as well as resource management, has actively conducted institutional changes for this purpose. In this context, land law has been implemented in line with Frelimo's objective of strengthening its local power base. The dominance of the state over traditional leaders has also been illustrated in Zimbabwe's fast-track resettlement. When examining debates on the role of traditional leaders in the land redistribution process, Alexander $(2018,151)$ concluded that they were 'influential only insofar as they subordinated themselves to the ZANU-PF's partisan project' on resettlement farms (Chapter 5 'Land Tenure Reform in Three Former Settler Colonies in Southern Africa').

In some countries, the state has monopolised the political space. A representative case is Rwanda. The chiefs, who were ethnically identified as Tutsi in the

${ }^{11}$ Republic of Zambia, The Land Act. See for example, Part II, 3. (4)(b)(d) and 8. (2)(3). 
colonial period, were expelled during the 'social revolution' just before independence. Although the second generation of the expelled group took power following the civil war in the 1990s, they have never attempted to restore traditional chieftaincy. In contrast, the former rebel ruling party, the Rwandan Patriotic Front (RPF), has repeated radical intervention in the land for power consolidation. Land tenure reform has been part of this project (Chapter 7 'Land Law Reform and Complex State-Building Process in Rwanda').

The Ethiopian highland may be a similar case, whereby a dominant ruling party utilised land law reform to consolidate the existing political order. In the country, the land registration programme was accelerated after the election in 2005, which was marked by the rise of the opposition party. The objective of hastily providing land certificates in this period has been interpreted as to "win back the support of the rural population and to undermine the chance of the opposition' (Dessalegn 2009, 68). It is well known that the Ethiopian People's Revolutionary Democratic Front (EPRDF) regime undertook land tenure reform at the same time as decentralisation and included a number of community participatory initiatives. Nevertheless, the provision of land certificates was utilised as an effective tool for the ruling party to mobilise popular support. In a similar vein, researchers, including Chinigò (2015) and Mekonnen (2018) evaluated that the EPRDF has attempted, through land registration, to consolidate its power base in rural areas and expand its capabilities to control land.

When examining the variation in the relationship between the state and traditional leaders, some interesting questions for further research were discovered. First, the nature of the relationship requires a very detailed investigation in connection with the type of macro-level political order. Ghana and Zambia, where traditional leaders markedly influence the state, have had relatively high scores on democracy because both countries have experienced regime changes through elections. In contrast, in our case studies, the position of traditional leaders is negligible or subjugated to the state, with the authoritarian and one-party dominant rule. This tendency is particularly pronounced for the countries in which the ruling party was once engaged in the civil war (Ethiopia, Mozambique, Rwanda). How can the relationship between the power of a chief and macro-level political order (democracy/authoritarian rule) be consistently understood? Understandably, traditional leaders tend to be influential over national-level political actors when the latter needs to attract the former in consideration of its rural electorate. The variation among African countries should be explained by taking the historical trajectory of each case into consideration. Systematic comparative studies will be invaluable for obtaining convincing answers to this question.

Another question concerns the tendency of the state to strengthen control over rural areas. As discussed above, our study revealed that in some African countries, the ruling parties have utilised land-related policies for their power consolidation. This makes us revisit the conventional understanding of the state of Africa. Despite the cliché of the African weak state (Hyden 1980; Jackson and Rosberg 1982; Herbst 2000), it is widely accepted that a number of African governments have recently 
consolidated political power with an authoritarian drive. ${ }^{12}$ In our case studies, the abovementioned three countries (Ethiopia, Mozambique, and Rwanda) clearly fall into this category. Are they examples of state building in the age of land reform? It seems too early to answer this question. Although our study shows that policy interventions in land have been effective and efficient tools for political mobilisation, this does not mean that state building has been successfully advanced in these countries. As the current situation in Ethiopia shows, top-down power consolidation with an authoritarian style can be fragile.

Land governance is deeply connected to political order. Good land governance contributes to long-term political stability because it functions as a built-in system for the stabilisation of macro-level political order. When land governance is perceived as legitimate from the eyes of ordinary land users, the ruler can benefit from the products of land users, who will, in turn, benefit from improved service from the ruler. The objective of land reform is to construct this virtuous circle, but, unfortunately, it is highly questionable if the land reform in Africa since the 1990s has created this.

\section{Structure of This Book}

This book includes eight case studies that analyse the context of recent land reform and rural change. Dealing with the Ghanaian case, Amanor (Chapter 2 'Land Administration, Chiefs, and Governance in Ghana') elucidates the 'longue durée' of the relationship between the state and the traditional leaders. Ghana is well known as a country whose chiefs have strongly influenced politics. Tracing back to the precolonial period, the author reveals how chiefs have relied on land for the consolidation and maintenance of their power, and describes the evolution of their relationships with the state. Due to the collusion between state officials and traditional leaders, recent land reforms have resulted in upholding the privileges of chiefs and have fallen short of protecting the rights of small farmers.

Chitonge (Chapter 3 ' "We Owned the Land Before the State was Established': The State, Traditional Authorities, and Land Policy in Africa') explains the complexity of the relationship between the state and traditional authorities regarding customary land administration. Claiming their legitimate rights over land allocation, the traditional leader has become a competitor and/or a collaborator of land management with the government, thus making their relationship ambiguous, sometimes strained, and sometimes colluded. The latter part of the chapter analyses the Zambian traditional leaders' protest of proposed land reforms and confirms their strong legitimacy and power, given not only by cultural and ethnic allegiance, but also by politicians' consideration for ensuring the rural electorate.

\footnotetext{
12 Based on various indexes of political dimensions including political rights and civil liberties, state of democracy, and governance, Harbeson (2013) demonstrated the increasing tendency of authoritarianism in Africa since the mid-2000s.
} 
Based on long-term fieldwork, Oyama (Chapter 4 'Renewed Patronage and Strengthened Authority of Chiefs Under the Scarcity of Customary Land in Zambia') explains what new land law has brought about in rural Zambia. Following the enactment of the 1995 Land Act that strengthened the power of traditional leaders over land, the chiefs began to issue original land titles called 'Land Allocation Form'. The forms differ from title deeds issued by the Ministry of Land but are considered completely effective at the local level. Many outsiders, including wealthy city dwellers and retirees, have obtained them by building a patronage network with the chief and, therefore, fostering a sense of land scarcity among villagers and urging them to acquire the same forms. This has further accelerated the sense of land scarcity. The chapter clearly shows the local dynamism of enclosure that was triggered by the new land law.

Sato (Chapter 5 'Land Tenure Reform in Three Former Settler Colonies in Southern Africa') also examines the role, function, and legitimacy of traditional leaders through a comparison of the land tenure reform for three former settler colonies in Southern Africa (Zimbabwe, Namibia, and South Africa). Although land restitution has attracted attention from the outside world, land tenure reform in the former native reserves (communal areas) has been considered critical and caused heated debates in each country. While all reforms have been centred on traditional leaders in rural land administration, the author problematises the excessive focus on them and recommends broadening the perspective for the improvement of people living in the communal area.

Aminaka (Chapter 6 'Politics of Land Resource Management in Mozambique') presents a clear picture of the Mozambican rural transformation during the economic boom. The reform has been implemented with other institutional changes, promoting FDI, as well as strengthening political control of the ruling party (Frelimo) over rural areas. Traditional leaders were officially recognised through the reform, but they also reorganised the community to ensure Frelimo's political influence. Land reform has been a part of Frelimo's project for the establishment and reinforcement of its power over rural areas in the interests of resource management and political mobilisation.

The picture is similar in Rwanda, as described by Takeuchi and Marara (Chapter 7 'Land Law Reform and Complex State-Building Process in Rwanda'). Following the military victory of the civil war in 1994, the RPF established and strengthened its control over the country. Policy interventions over land have been a key component of the RPF-led state-building process. By tracing policy interventions in rural areas in the post-civil war Rwanda, the chapter shows how the government has asserted its control over rural areas and revisits the meaning of land tenure reform. Moreover, the authors show the difficulty of institutionalising the modern land management system, including land registration. As a result, the state-building process in the country will never be straightforward.

The commercialisation of land has been one of the most conspicuous aspects of recent rural changes in Africa. Focussing on this point, Teshome (Chapter 8 'PostCold War Ethiopian Land Policy and State Power in Land Commercialisation') illustrates that major schemes for the promotion of land commercialisation were organised in land policy pursued under the government led by the EPRDF, and the roles of the 
main donor for the implementation of the policy. This shows that the government and donors deliberately promoted land commercialisation in close collaboration.

Narh (Chapter 9 'Traversing State, Agribusinesses, and Farmers' Land Discourse in Kenyan Commercial Intensive Agriculture') examines the effects of the Kenyan land tenure reform and casts doubt on the simple assumption that strengthening users' rights will improve agricultural productivity. As a result of the policy providing land title carried out since the 1950s, Kenyan farmers have been generally provided with strong individual rights over their properties. Based on his fieldwork in the sugarcane growing communities in western Kenya, the author argues that the farmers have lost control of their lands. Their initiatives for devising productive methods have been suffocated because of the heavy dependence of farmers on the sugarcane company in terms of inputs and infrastructure, as well as knowledge, for production. The chapter indicates that the provision of individual property rights will not guarantee high agricultural productivity.

Acknowledgements I am deeply grateful for the invaluable comments from Kojo S. Amanor on the earlier version of this chapter.

\section{References}

Alden-Wily, L. 2011. 'The law is to blame': The vulnerable status of common property rights in Sub-Saharan Africa. Development and Change 42 (3): 733-757.

Alden Wily, L. 2014. The law and land grabbing: Friend or foe? Law and Development Review 7 (2): 207-242.

Alexander, J. 2018. The politics of states and chiefs in Zimbabwe. In The politics of custom: Chiefship, capital, and the state in contemporary Africa, ed. John L. Comaroff and Jean Comaroff, 134-161. Chicago and London: The University of Chicago Press.

Amanor, K.S. 2001. Land, labour and the family in southern Ghana: A critique of land policy under neo-liberalisation. Uppsala: Nordic Africa Institute.

Amanor, K.S. 2009. Securing land rights in Ghana. In Legalising land rights: Local practices, state responses and tenure security in Africa, Asia and Latin America, ed. J.M. Ubink, A.J. Hoekema, and W.J. Assies, 97-131. Leiden: Leiden University Press.

Amanor, K.S. 2010. Family values, land sales and agricultural commodification in South-Eastern Ghana. Africa 80 (1): 104-125.

Berry, S. 1993. No condition is permanent: The social dynamics of agrarian change in sub-Sharan Africa. Madison: The University of Wisconsin Press.

Bonneuil, C. 2000. Development as experiment: Science and state building in late colonial and postcolonial Africa, 1930-1970. Osiris 15 (1): 258-281.

Boone, C. 2014. Property and political order in Africa: Land rights and the structure of politics. Cambridge: Cambridge University Press.

Boone, C. 2018. Shifting visions of property under competing political regimes: Changing uses of Côte d'Ivoire's 1998 land law. The Journal of Modern African Studies 56 (2): 189-216.

Boone, C. 2018. Property and land institutions: Origins, variations and political effects. In Institutions and democracy in Africa: How the rules of the game shape political developments, ed. $\mathrm{N}$. Cheeseman, 61-91. Cambridge: Cambridge University Press. 
Bruce, J.W. 1988. A perspective on indigenous land tenure: Systems and land concentration. In Land and society in contemporary Africa, ed. E. Downs and S.P. Reyna, 23-52. Hanover: University of New England Press.

Bukari, K.N., P. Sow, and J. Scheffran. 2018. Cooperation and co-existence between farmers and herders in the midst of violent farmer-herder conflicts in Ghana. African Studies Review 61 (2): 78-102.

Chanock, M. 1991. Paradigms, policies and property: A review of the customary law of land tenure. In Law in colonial Africa, ed. K. Mann and R. Roberts, 61-84. Portsmouth: Heinemann.

Chinigò, D. 2015. The politics of land registration in Ethiopia: Territorialising state power in the rural milieu. Review of African Political Economy 42 (144): 174-189.

Coldham, S. 1978. The effect of registration of title upon customary land rights in Kenya. Journal of African Law 22 (2): 91-111.

Coldham, S. 1979. Land-tenure reform in Kenya: The limits of law. The Journal of Modern African Studies 17 (4): 615-627.

de Soto, H. 2000. The mystery of capital: Why capitalism triumphs in the West and fails everywhere else. London: Black Swan.

Deininger, K., C. Augustinus, S. Enemark, and P. Munro-Faure. 2010. Innovations in land rights recognition, administration, and governance. Washington, DC: World Bank.

Deininger, K., and H. Binswanger. 2001. The evolution of the World Bank's land policy. In Access to land, rural poverty, and public action, ed. A. De Janvry, G. Gordillo, J.-P. Platteau, and E. Sadoulet, 406-440. Oxford: Oxford University Press.

Deininger, K., and D. Byerlee. 2011. Rising global interest in farmland: Can it yield sustainable and equitable benefits? Washington, DC: World Bank.

Deininger, K., and G. Feder. 2009. Land registration, governance, and development: Evidence and implications for policy. The World Bank Research Observer 24 (2): 233-266.

Dessalegn, R. 2009. Land rights and tenure security: Rural land registration in Ethiopia. In Legalizing land rights: Local practices, state responses and tenure security in Africa, Asia and Latin America, ed. J.M. Ubink, A.J. Hoekema, and W.J. Assies, 59-95. Leiden: Leiden University Press.

Feder, G., and R. Noronha. 1987. Land rights systems and agricultural development in Sub-Saharan Africa. World Bank Research Observer 2 (2): 143-169.

Harbeson, J.W. 2013. Democracy, autocracy, and the sub-Saharan African state. In Africa in world politics: Engaging a changing global order, ed. J.W. Harbeson and D. Rothchild, 83-123. Boulder: Westview Press.

Haugerud, A. 1989. Land tenure and agrarian change in Kenya. Africa 59 (1): 61-90.

Herbst, J. 2000. States and power in Africa: Comparative lessons in authority and control. Princeton: Princeton University Press.

Holden, S.T., K. Otsuka, and K. Deininger. 2013. Land tenure reforms, poverty and natural resource management: Conceptual framework. In Land tenure reform in Asia and Africa: Assessing impacts on poverty and natural resource management, ed. S.T. Holden, K. Otsuka, and K. Deininger, 1-26. Basingstoke: Palgrave MacMillan.

Hyden, G. 1980. Beyond ujamaa in Tanzania: Underdevelopment and an uncaptured peasantry. London: Heinemann.

Jackson, R.H., and C.G. Rosberg. 1982. Why Africa's weak states persist: The empirical and the juridical in statehood. World Politics 35 (1): 1-24.

Lavigne-Delville, P., and A.-C. Moalic. 2019. Territorialities, spatial inequalities and the formalization of land rights in Central Benin. Africa 89 (2): 329-352.

Lefort, R. 2012. Free market economy, 'developmental state' and party-state hegemony in Ethiopia: The case of the model farmers. The Journal of Modern African Studies 50 (4): 681-706.

Manji, A. 2006. The politics of land reform in Africa: From communal tenure to free markets. London: Zed Books.

Martín, V.O.M., L.M.J. Darias, and C.S.M. Fernández. 2019. Agrarian reforms in Africa 1980-2016: Solution or evolution of the agrarian question? Africa 89 (3): 586-607. 
Mekonnen, F.A. 2018. Rural land registration in Ethiopia: Myths and Realities. Law and Society Review 52 (4): 1060-1097.

Moore, S.F. 1998. Changing African land tenure: Reflections on the incapacities of the state. European Journal of Development Research 10 (2): 33-49.

Organization for Economic Co-Operation and Development (OECD). 2008a. State building in situations of fragility. Paris.

OECD. 2008b. Concepts and dilemmas of state building in fragile situations. Paris.

Peters, P.E. 2002. The limits of negotiability: Security, equity and class formation in Africa's land systems. In Negotiating Property in Africa, ed. K. Juul and C. Lund, 45-66. Portsmouth: Heinemann.

Peters, P.E. 2013. Conflicts over land and threats to customary tenure in Africa. African Affairs 112 (449): 543-562.

Sassen, S. 2013. Land grabs today: Feeding the disassembling of national territory. Globalizations 10 (1): $25-46$.

Shen, X. ed. with X. Sun. 2012. Untying the land knot: Making equitable, efficient, and sustainable use of industrial and commercial land. Washington, DC: World Bank.

Shipton, P. 1988. The Kenyan land tenure reform: Misunderstanding in the public creation of private property. In Land and society in contemporary Africa, ed. R.E. Downs and P. Reyna, 91-135. Hanover: University Press of New England.

Sikor, T., and D. Müller. 2009. The limits of state-led land reform: An introduction. World Development 37 (8): 1307-1316.

Sjaastad, E., and B. Cousins. 2009. Formalisation of land rights in the South: An overview. Land Use Policy 26 (1): 1-9.

Staner, P. 1955. Les paysannats indigènes du Congo belge et du Ruanda-Urundi. Bulletin Agricole Du Congo Belge 46 (3): 467-558.

Takeuchi, S. 2014. The evolution of land policy in African State building. In State building and development, ed. K. Otsuka and T. Shiraishi, 95-113. London: Routledge.

Takeuchi, S. 2021. When African Potentials fail to work: The background to recent land conflicts in Africa. In African politics of survival extraversion and informality in the contemporary World, eds. M. Endo, A.K. Onoma, and M. Neocosmos, 121-146. Bamenda: Langaa RPCIG.

Ubink, J.M. 2007. Tenure security: Wishful policy thinking or reality? A case from peri-urban Ghana. Journal of African Law 51 (2): 215-248.

Ubink, J.M. 2009. Legalising land rights in Africa, Asia and Latin America: An introduction. In Legalising land rights: Local practice, state responses and tenure security in Africa, Asia and Latin America, ed. J.M. Ubink, A.J. Hoekema, and W.J. Assies, 7-31. Leiden: Leiden University Press.

Woodhouse, P. 2003. African enclosures: A default mode of development. World Development 31 (10): 1705-1720.

World Bank. 1975. Land reform: Sector policy paper. Washington, DC: World Bank.

World Bank. 1981. Accelerated development in Sub-Saharan Africa: An agenda for action. Washington, DC: World Bank.

World Bank. 2009. Awakening Africa's sleeping giant: Prospects for commercial agriculture in the Guinea savannah zone and beyond. Washington, DC: World Bank. 
Open Access This chapter is licensed under the terms of the Creative Commons Attribution 4.0 International License (http://creativecommons.org/licenses/by/4.0/), which permits use, sharing, adaptation, distribution and reproduction in any medium or format, as long as you give appropriate credit to the original author(s) and the source, provide a link to the Creative Commons license and indicate if changes were made.

The images or other third party material in this chapter are included in the chapter's Creative Commons license, unless indicated otherwise in a credit line to the material. If material is not included in the chapter's Creative Commons license and your intended use is not permitted by statutory regulation or exceeds the permitted use, you will need to obtain permission directly from the copyright holder.

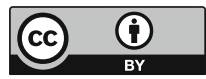

